\title{
Piotr Lesiak
}

Dr hab. inż.

Wyższa Szkoła Ekonomii i Innowacji w Lublinie,

Wydział Transportu i Informatyki

piotr.lesiak@wsei.lublin.pl

\section{Rafał Podsiadło}

Dr inż.

Uniwersytet Technologiczno-Humanistyczny

im. K. Pułaskiego w Radomiu,

Wydział Transportu i Elektrotechniki

r.podsiadlo@uthrad.pl

DOI: 10.35117/A_ENG_19_06_03

\section{Simulation of geometric pattern of surface flaws in railway rails}

\begin{abstract}
The paper presents selected models of geometric patterns of surface flaws in railway rails. The simulation based on Bezier's splines has been carried out using UM Loco simulation software. It allows for the simulation of the rail profile with pattern flaws. These flaws have been used to simulate dynamic interaction between the vehicle and the track for the freight carriage moving with different speeds. The impact of the flaw dimensions on the contact forces have been analyzed
\end{abstract}

Keywords: Computer graphics; Rails; Patterns of surface flaws; Simulation; Contact forces

\section{Introduction}

Surface defects of rail rails, especially those belonging to the RCF contact group - Rolling Contact Fatigue, belong to the growing group of rail damage [1], [3] and [9]. The consequences of their development, as a rule, are manifested by the complex unevenness of the rail running surface, which poses a threat to operation, due to the increase in contact forces between track and vehicle. This is a reverse phenomenon to the known and commonly diagnosed by PKP PLK S.A. damage to the rolling surfaces of the wheels [7], but with similar effects on the track. Therefore, the authors decided to model in numerical form the geometry of several typical patterns of these defects, in order to objectively assess them for potential cracks (fractures) of the rails in these sensitive places. This is an extremely important issue, as it entails not only an increase in repair costs, but above all a deterioration in the state of train traffic safety. The first attempts to analyze these problems made by the authors are presented in [8]. The co-author also created physical models of surface defect patterns in rails, Head Checking and Squat, but for the purpose of diagnostic tests using the laser scatterometry method [6].Using in practice the models of defect models proposed by the authors allows an objective metrological assessment of the values of the maximum dynamic contact forces accompanying the train crossing in relation to actual defects of similar shape in the railway track. For this purpose, the impact of changes in standard dimensions on the value of these forces was estimated.

\section{Presentation of surface defect patterns}

In order to visually present the analyzed types of surface defect patterns, 3D models were created for them, Fig. 1. They correspond to real defects encountered in the track, Fig. 2. There can be distinguished four types of defects: split, spalling [12], squat and strain [4]. 
Their width and depth dimensions were defined in order to further assess them for operational hazards.

a)

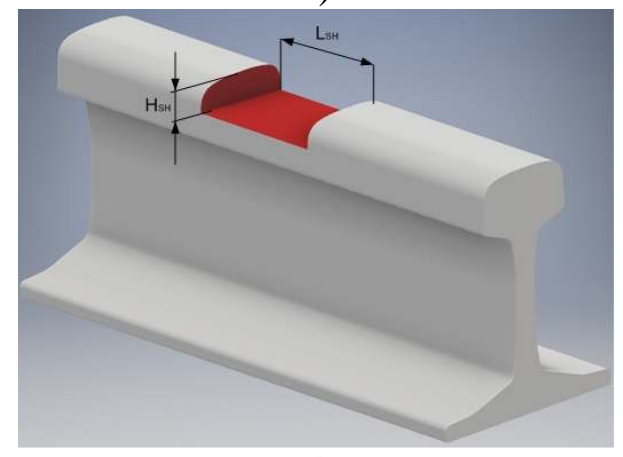

c)

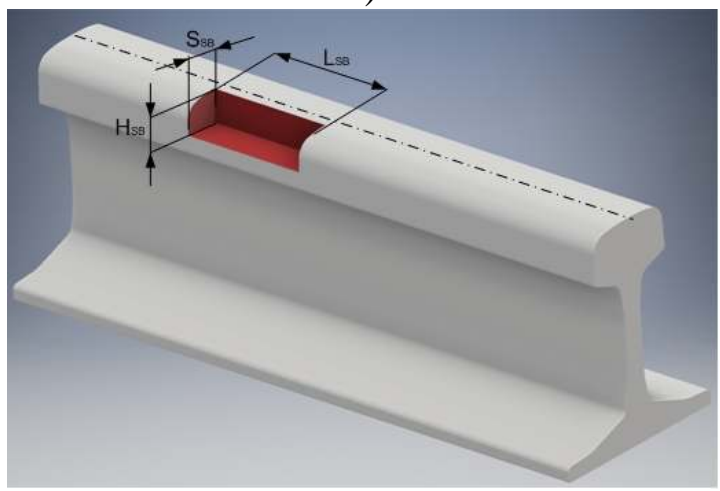

e)

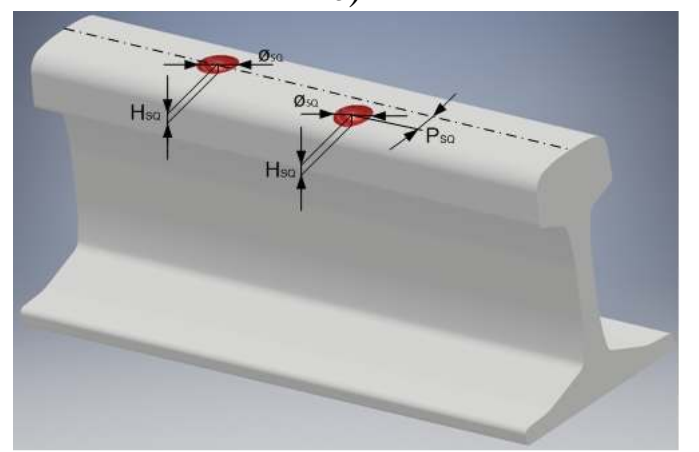

b)

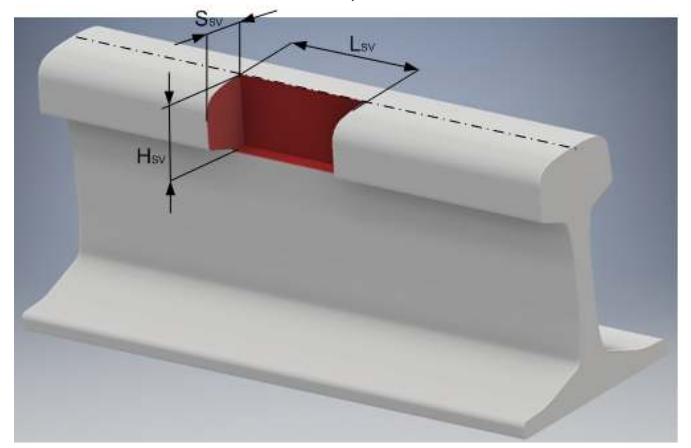

d)

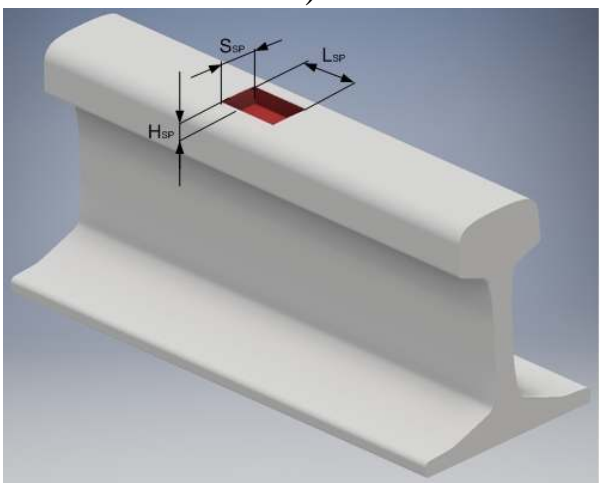

f)

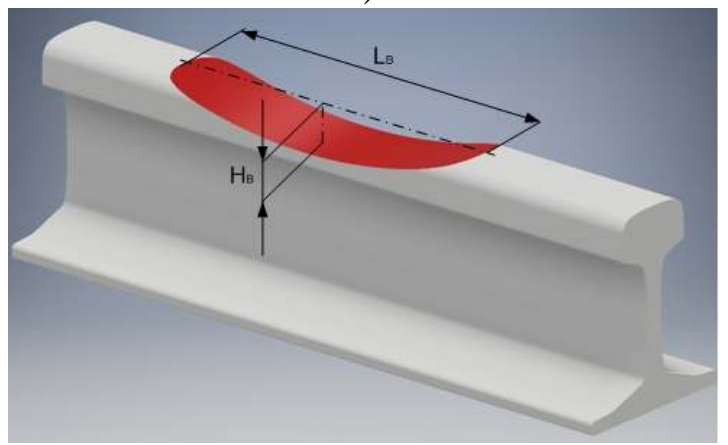

1. 3D presentation of surface defects: a) Horizontal split, b) Vertical split c) Side split, d) Spalling, e) Squat in the longitudinal axis of the rail and shifted, f) Strain (own study)

The defects were modelled on a UIC60 profile rail. Analogies of real defects corresponding to their models are shown in Fig. 2. The first is the horizontal crack, which is characterized by a gradual separation of the upper part of the rail head (Horizontal Split Head) - catalogue No. 212. The crack begins inside the railhead and proceeds parallel in all directions to the running surface. At a later stage, a piece of metal is separated, which causes a local lowering of the rolling surface, Fig. 1a and $\mathbf{2 a}$.

The vertical fracture of the railhead becomes the beginning of a defect, as a result of which half of the railhead falls to the neck (Vertical Split Head), Fig. 1b and $\mathbf{2 b}$ (catalogue No. 213) [4]. A smaller range of this phenomenon, which is, among other things, an in-depth effect of shelling defects, is lateral Split. Then the edge of the railhead breaks off, Fig. 1c and 2c (catalogue No. 2222).

Another damage to the rolling surface of the rail, of metallurgical origin, is chipping off a fragment of the rolling surface, i.e. Center Rail Spalling, Fig. 1d and 2d. This defect begins 
with a shallow horizon, causing the rolling surface of the rail to gradually lower. The defects in Fig. 1e and 2e are popular squats, representing a group of contact-stress defects (catalogue No. 227). They can occur in various places of the rail running surface, in its horizontal axis, or move to the center of the track, where the greatest load on the rim occurs.

The last representative of the surface defects considered in the work is classic strain, Fig.1f and $2 \mathbf{f}$ (catalogue No. 2252). They occur especially in places where heavy freight depots start, usually before semaphores.

a)

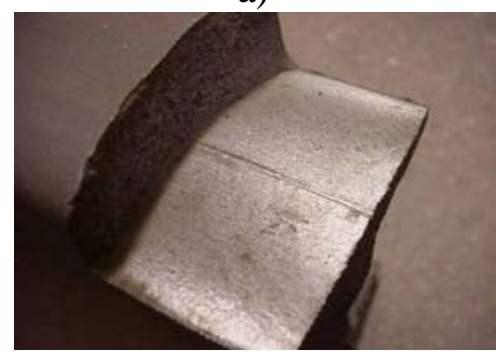

d)

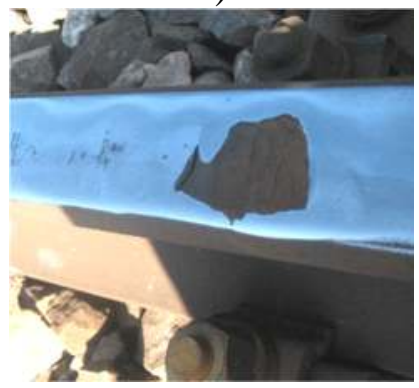

b)

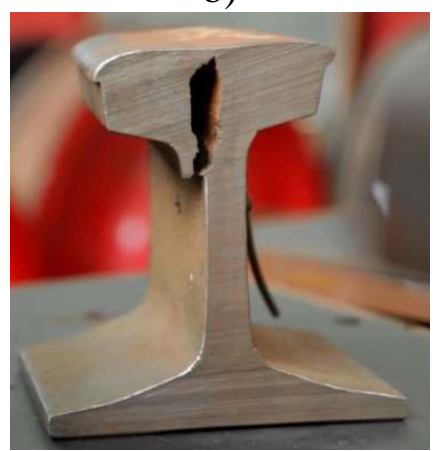

e)

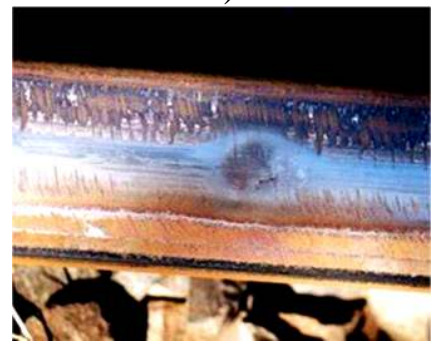

c)

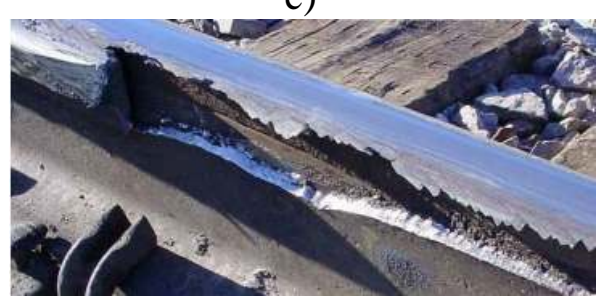

f)

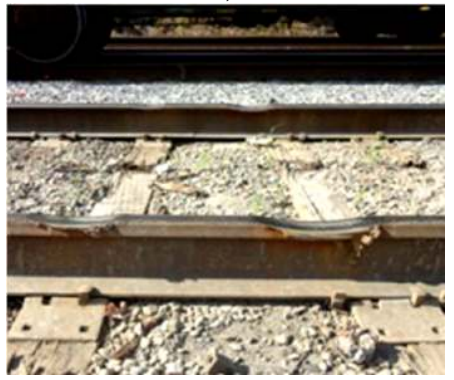

2. Real defects equivalent to the 3D presentation in Fig. 1. [2], [12], [13], [14] i [16]

\section{Algorithm for numerical modelling of the geometry of defect patterns profiles}

For modelling surface defect patterns in rails, Bézier curves were used [5]. These are parametric curves commonly used in vector graphics. Each coordinate of the curve point is a function of the real number. Due to the nature of these functions, we are talking about polynomial curves and rational curves. The curve is defined by a control broken, consisting of control points. The shape of the Bézier curve is described by polynomials for which the domain $t$ has been assumed $\in[0,1]$. The degree of polynomial directly depends on the number of control points - it is $n$ (number of control points minus one). Fig. 3 shows an example Bézier $C$ curve, its control points 1, 2, 3, 4, and its broken control $P$.

The formula for a Bézier curve with more than 4 control points can be described by a polynomial:

$$
\begin{aligned}
\mathbf{B}(t)= & \sum_{i=0}^{n}\left(\begin{array}{c}
n \\
i
\end{array}\right)(1-t)^{n-i} t^{i} \mathbf{P}_{i} \\
= & (1-t)^{n} \mathbf{P}_{0}+\left(\begin{array}{c}
n \\
1
\end{array}\right)(1-t)^{n-1} t \mathbf{P}_{1}+\cdots \\
& \cdots+\left(\begin{array}{c}
n \\
n-1
\end{array}\right)(1-t) t^{n-1} \mathbf{P}_{n-1}+t^{n} \mathbf{P}_{n}, \quad t \in[0,1]
\end{aligned}
$$

where: 


$$
\left(\begin{array}{l}
n \\
i
\end{array}\right)=\frac{n !}{i !(n-i) !}
$$

$n$-degree of polynomial describing the Bézier curve,

$i$ - number of checkpoints

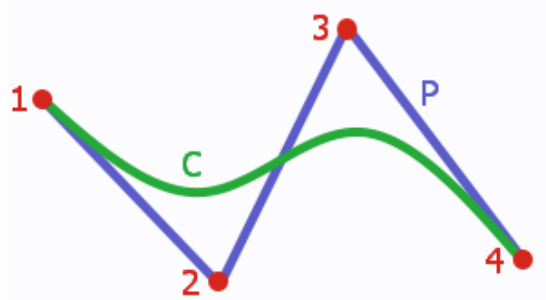

3. An example of creating a Bézier curve

The simulation studies used the UM Loco program [11], [17], where Bézier curves were implemented. By defining profile points, assumed reference patterns were obtained. Fig. 4 shows the cases from Fig. 1, except for strain, which is created by gluing multiple profiles. To determine the contact points, a rim outline was applied to the profiles. Examples of coordinates for selected defect pattern profiles are shown in Table 1, along with the legend. The term S (Spline) means a spline function. This function is continuous and has continuous derivatives. This method uses functions defined as low-degree polynomials separately for each segment between neighbouring interpolation nodes. However, these local polynomials are selected so that, in addition to interpolation conditions, they meet the conditions for gluing in such a way that the entire function is a function of appropriate regularity.

a)

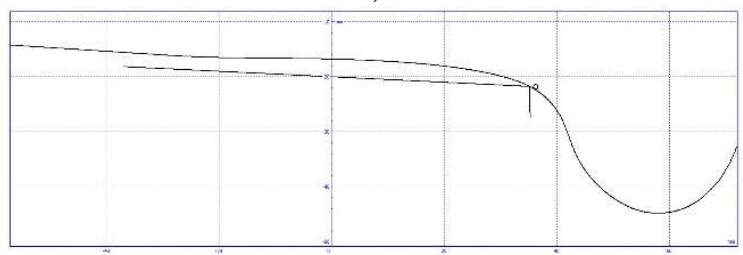

c)

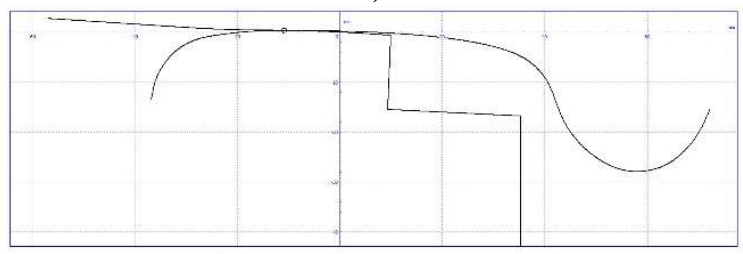

e)

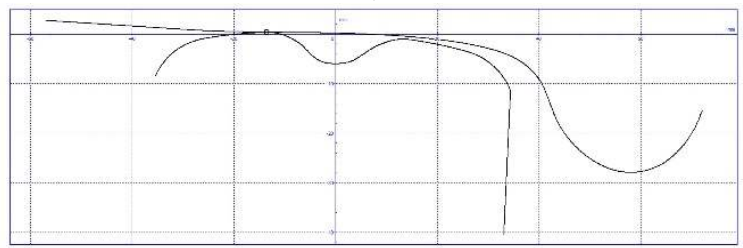

b)

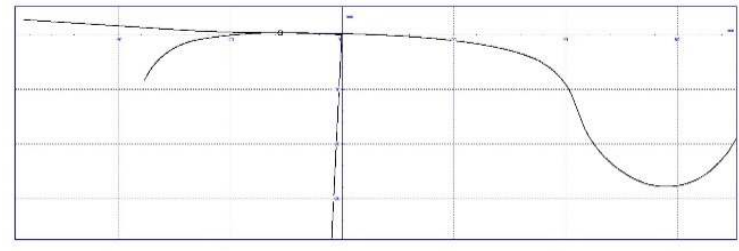

d)

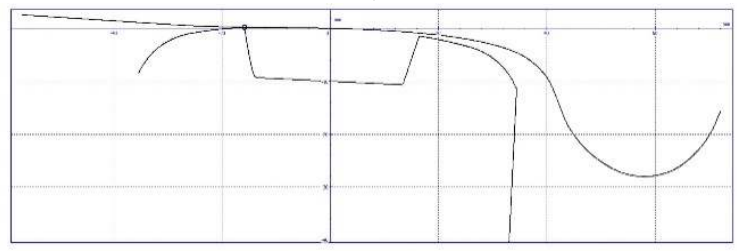

f)

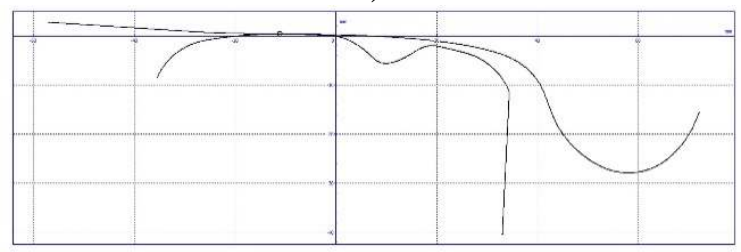

4. Profile defect patterns in cooperation with the wheel running surface: a) Horizontal split b) Vertical split, c) Side split, d) Spalling, e) Squat in the longitudinal axis of the rail f) Squat offset from the longitudinal axis of the rail (own work) 
The B-spline curve is one of the most commonly used parametric representations of spline curves. It is characterized by two parameters: $\mathrm{n}$ - the degree of spliced polynomial curves (in practice, usually small, 2,3 or 4 , less often more), $\mathrm{m}$ - the number of subcompartments on which subsequent parts of the curve are defined. It is represented by $\mathrm{m}-\mathrm{n}$ Bézier curves, however, control points are not enough to correctly determine this number of curves. Additional points must be found to construct all 3rd degree Bézier curves in such a way that parametric continuity is maintained.

\section{Examination of the impact of defect patterns sizes on contact forces}

The values of wheel-rail contact forces were tested depending on the size of selected surface defects during the passage of a freight wagon. The simulation used a wagon equipped with daimond bogies, Fig. 5. The model of this wagon was used by the authors in [7], [10] and was created in the UM LOCO package [17]. Its speed was $V=20 i 80 \mathrm{~km} / \mathrm{h}$, and the weight of the box $\mathrm{M}_{\mathrm{p}}=30 \mathrm{t}$. All analyzes were considered for set 1, as in Fig. 5a.The railway track was modelled as straight, in the form of an infinitely long beam with elastic support. It was conventionally assumed that the track is hard with damping $k_{p}=8,5.10^{7} \mathrm{~N} / \mathrm{m}$ and elasticity $c_{p}=3,8.10^{4} \mathrm{~N} / \mathrm{m}$. When the wagon wheels roll over within the surface patterns of rail defects, the pressure force of the wheels dynamically changes, Fig. 6. And so for the horizontal defect pattern model Split, as in Figs. 1a and 2a, the effect of wagon speed was compared in Figs. The dynamic load force of the $\mathrm{Q}_{\mathrm{d}}$ rail through the wheel of set 1 , regardless of speed, is about $50 \mathrm{kN}$. However, momentary changes in $\mathrm{Q}_{\mathrm{r}}$ reaction forces are important.

At low speed $\mathrm{V}=20 \mathrm{~km} / \mathrm{h}$, the maximum of this force is significantly higher, about 260 $\mathrm{kN}$, compared to the speed of $\mathrm{V}=80 \mathrm{~km} / \mathrm{h}$, where it is only $110 \mathrm{kN}$. After the wheel has moved over the edge (updip) of the defect pattern, it is first relieved and then impacted to the bottom of the defect, with the inertial suspension system of the wagon cart having less time at higher speed, hence the impact force $\mathrm{Q}_{\mathrm{r}}$ significantly decreases. It should be noted that wheel unloading for the speed $\mathrm{V}=20 \mathrm{~km} / \mathrm{h}$ are repeated, which can be interpreted by the loss of its contact within the defect pattern. After rolling over the other edge, the wheel already on the undamaged rail performs a cycle of damped vibrations, with their amplitude decreasing as the speed increases. To sum up, the wagon travel along the Split horizontal defect pattern is less onerous for the track as speed increases 
Tab. 1. Coordinates of defect profile patterns (own study)

\begin{tabular}{|c|c|c|c|c|c|c|c|c|c|c|c|}
\hline \multicolumn{6}{|c|}{$\begin{array}{l}\text { Squat defect pattern profile located in the rail } \\
\text { axis (Fig. 4e) }\end{array}$} & \multicolumn{6}{|c|}{ Spalling defect pattern profile (Fig. 4d) } \\
\hline Wsp X & Wsp Y & Typ & Wsp X & Wsp Y & Typ & Wsp X & Wsp Y & Typ & Wsp X & Wsp Y & Typ \\
\hline & -38.6 & $L^{\prime \prime}$ & 16.46 & -0.61 & $\mathrm{~s}$ & & -38.6 & $L$ & 16.46 & -0.61 & c \\
\hline-37.1 & -36.12 & L & 19.13 & -0.95 & $\mathrm{~s}$ & -37.1 & -36.12 & L & 19.13 & -0.95 & $\mathrm{~S}$ \\
\hline-36.7 & -28.7 & L & 21.90 & -1.40 & $\mathrm{~s}$ & -36.7 & -28.7 & L & 21.9 & -1.4 & s \\
\hline-36.5 & -23.8 & L & 24.76 & -1.97 & $\mathrm{~s}$ & $\begin{array}{l}-36.5 \\
-36.1\end{array}$ & -23.8 & L & 24.76 & -1.97 & s \\
\hline $\begin{array}{l}-36.1 \\
-35.68\end{array}$ & $\begin{array}{l}-15.3 \\
-1204\end{array}$ & $\begin{array}{l}\mathrm{L} \\
\mathrm{B}\end{array}$ & 26.24 & -2.31 & $\mathrm{~s}$ & $\begin{array}{l}-36.1 \\
-35.68\end{array}$ & -15.3 & $\begin{array}{l}L \\
B\end{array}$ & 26.24 & -2.31 & $\mathrm{~s}$ \\
\hline $\begin{array}{l}-35.68 \\
-34.63\end{array}$ & $\begin{array}{l}-12.04 \\
-9.11\end{array}$ & $\begin{array}{l}B \\
B\end{array}$ & 27.67 & -2.76 & S & $\begin{array}{l}-35.68 \\
-34.63\end{array}$ & -12.04 & $\begin{array}{l}B \\
B\end{array}$ & 27.67 & -2.76 & $\mathrm{~s}$ \\
\hline $\begin{array}{l}-34.63 \\
-32.95\end{array}$ & -6.54 & B & 29.02 & -3.36 & $\mathrm{~s}$ & $\begin{array}{l}-34.63 \\
-32.95\end{array}$ & $\begin{array}{l}-9.11 \\
-6.54\end{array}$ & $\begin{array}{l}\text { B } \\
B\end{array}$ & 29.02 & -3.36 & S \\
\hline-31.89 & -5.42 & B & 30.27 & -4.11 & S & -31.89 & -5.42 & B & 30.27 & -4.11 & $\mathrm{~s}$ \\
\hline-30.70 & -4.43 & B & 31.43 & -4.98 & $\mathrm{~s}$ & -30.7 & -4.43 & B & 31.43 & -4.98 & S \\
\hline-29.38 & -3.58 & B & 32.48 & -5.98 & $\mathrm{~s}$ & -29.38 & -3.58 & B & 32.48 & -5.98 & $\mathrm{~s}$ \\
\hline-27.95 & -2.88 & B & 33.41 & -7.08 & S & -27.95 & -2.88 & B & 33.41 & -7.08 & S \\
\hline-26.42 & -2.36 & B & 34.21 & -8.28 & s & -26.42 & -2.36 & B & 34.21 & -8.28 & S \\
\hline-24.81 & -1.99 & B & & -9.57 & s & -24.81 & -1.99 & B & 34.88 & -9.57 & s \\
\hline-23.24 & -1.66 & B & $\begin{array}{l}34.88 \\
35.41\end{array}$ & & s & -23.24 & -1.66 & B & 35.41 & -10.94 & S \\
\hline-21.70 & -1.37 & B & 35.41 & -10.94 & S & -21.7 & -1.37 & B & 35.78 & -12.38 & $\mathrm{~s}$ \\
\hline-18.71 & -0.89 & B & 35.78 & -12.38 & $\mathrm{~s}$ & -18.71 & -0.89 & B & 35.99 & -13.88 & $\mathrm{~s}$ \\
\hline-15.84 & -0.55 & $\mathrm{~s}$ & 35.99 & -13.88 & S & -15.84 & -0.55 & C & 36.07 & -15.4 & $\mathrm{~s}$ \\
\hline-13.09 & -0.31 & $\mathrm{~s}$ & 36.07 & -15.40 & S & -13.09 & & $-10 \mathrm{~S}$ & 36.14 & -16.87 & $\mathrm{~s}$ \\
\hline-10.43 & -0.18 & $\mathrm{~s}$ & 36.14 & -16.87 & $S$ & -10.43 & & $-10 \mathrm{~L}$ & 36.21 & & \\
\hline-7.86 & -0.10 & $\mathrm{~s}$ & 36.21 & -18.30 & $S$ & -7.86 & & $-10 \mathrm{~L}$ & 36.35 & -21.05 & L \\
\hline-5.7 & -0.8 & $\mathrm{~S}$ & 36.35 & -21.05 & L & -5.39 & & $-10 \mathrm{~L}$ & 36.5 & -23.8 & L \\
\hline $\begin{array}{r}-4.3 \\
-2.9\end{array}$ & -2.7 & $\begin{array}{l}S \\
s\end{array}$ & 36.5 & -23.8 & L & -2.97 & & $-10 L$ & 36.61 & -26.24 & L \\
\hline $\begin{array}{c}-2.9 \\
0.3\end{array}$ & $\begin{array}{l}-4.8 \\
-5.9\end{array}$ & $\begin{array}{l}\mathrm{S} \\
\mathrm{S}\end{array}$ & 36.61 & -26.24 & $\mathrm{~L}$ & -0.6 & & $-10 \mathrm{~L}$ & 36.73 & -28.73 & $\mathrm{~L}$ \\
\hline 3.6 & -4.8 & s & 36.73 & -28.73 & L & $\begin{array}{l}1.75 \\
4.1\end{array}$ & & $\begin{array}{l}-10 L \\
-10 L\end{array}$ & 36.86 & -31.19 & L \\
\hline 6.5 & -1.1 & $\mathrm{~s}$ & 36.86 & -31.19 & L & $\begin{array}{l}4.1 \\
6.47\end{array}$ & & $\begin{array}{l}-10 \mathrm{~L} \\
-10 \mathrm{~L}\end{array}$ & 36.98 & -33.65 & L \\
\hline 8.87 & -0.13 & $\mathrm{~s}$ & 36.98 & -33.65 & L & 8.87 & & $-10 \mathrm{~L}$ & 37.1 & -36.12 & L \\
\hline 11.34 & -0.21 & $\mathrm{~s}$ & 37.1 & -36.12 & L & 11.34 & & $-10 \mathrm{~L}$ & 35 & -38.641 & $\mathrm{~L}$ \\
\hline 13.86 & -0.37 & $\mathrm{~s}$ & 35 & -38.641 & L & 13.86 & & $-10 \mathrm{~S}$ & & & \\
\hline
\end{tabular}

Legend: L - straight line, S - S-spline function, B - B-spline curve, C - rounding

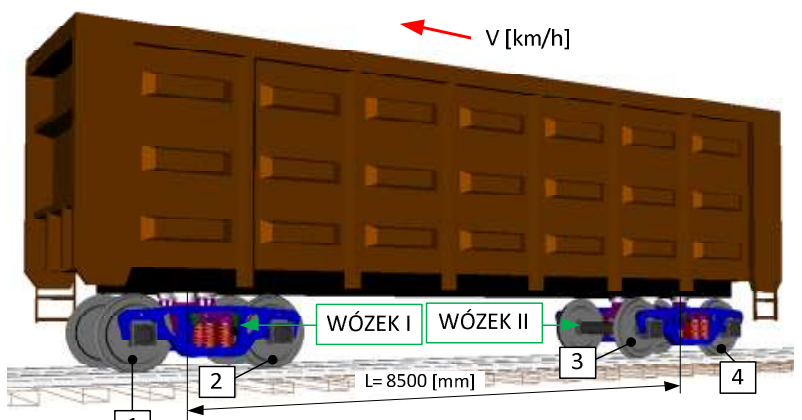

c)

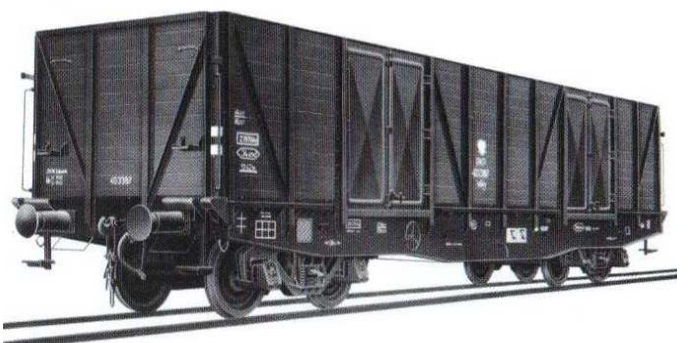

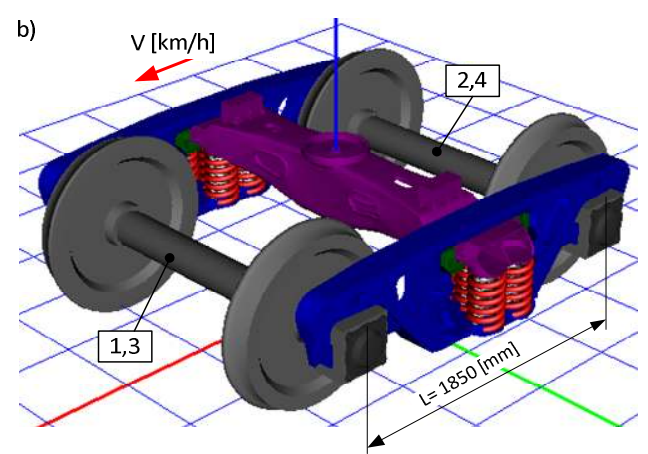

5. View of the freight wagon used in the simulations: a) freight wagon and b) a bogie created in UM LOCO, c) a real wagon equipped with daimond bogies 
a)

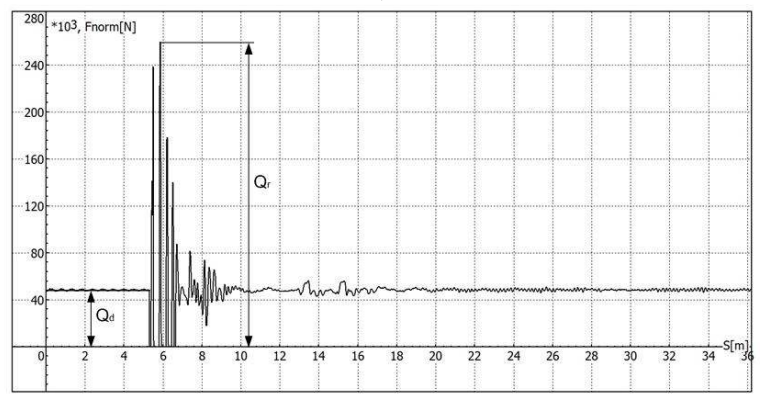

c)

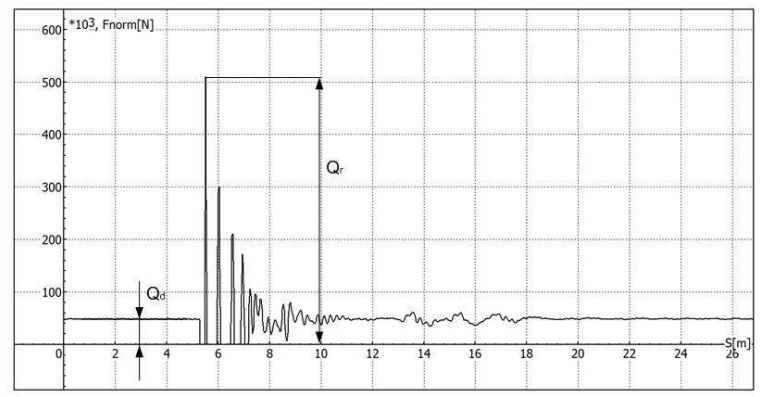

b)

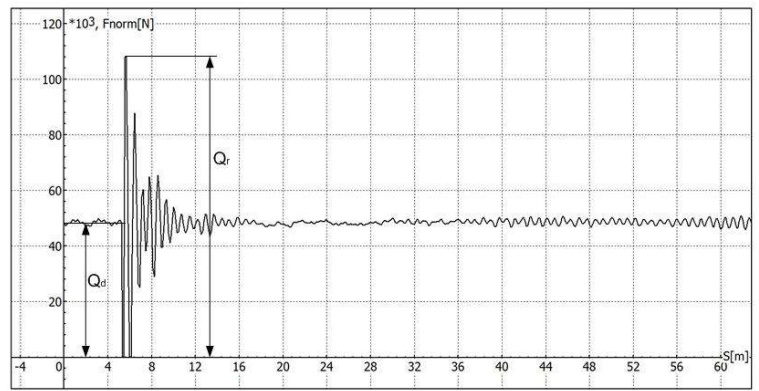

d)

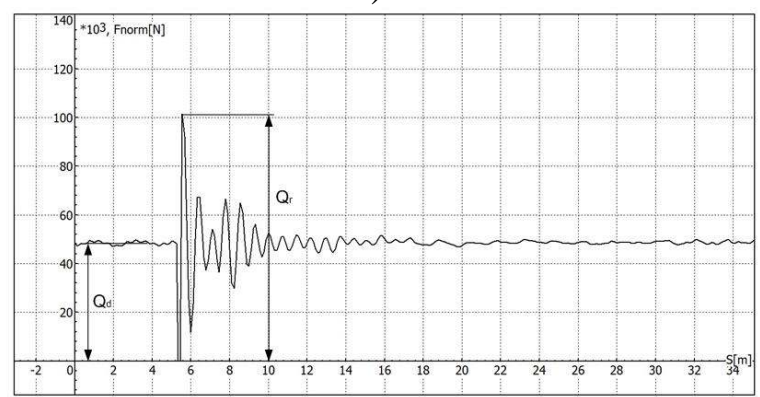

6. Dynamic changes in vertical contact force wheel-rail defect pattern: a) Horizontal split 200 $\mathrm{mm}$ long and $10 \mathrm{~mm}$ deep (after exceeding $15 \mathrm{~mm}$ there is a possibility of derailment - Fig.

7b), at a speed of $20 \mathrm{~km} / \mathrm{h}$, b) as a) $\mathrm{V}=80 \mathrm{~km} / \mathrm{h}$, c) and d) Vertical split as horizontal respectively) and b) (own study)

Similar phenomena occur for the vertical Split pattern, where an increase in speed to $\mathrm{V}=$ $80 \mathrm{~km} / \mathrm{h}$ significantly improves the wagon motion stability, Fig. 6d, and reduces the $\mathrm{Q}_{\mathrm{r}}$ reaction force to $105 \mathrm{kN}$ from $550 \mathrm{kN}$ at $\mathrm{V}=20 \mathrm{~km} / \mathrm{h}$. Therefore, this defect pattern, especially for low speeds and considerable length, creates a real danger of derailment not only due to overloading of the track but also to the transverse movement of the set, Fig. 1b. The shapes and amplitudes of contact force waveforms for horizontal and vertical split patterns at higher speeds are very similar, Fig. $\mathbf{6 b}$ and $\mathbf{6 d}$, which shows the similarity of their impact on a rail vehicle. The considerations regarding dynamic phenomena for the Horizontal Split pattern from Fig. 1a is also confirmed by the example graphs from Figs. 7a and 7b, which concern the assessment of the geometry of this defect for the value of reaction forces. And so, for the length of this defect $\mathrm{L}_{\mathrm{HS}}=200 \mathrm{~mm}$, at a speed of $\mathrm{V}=20 \mathrm{~km} / \mathrm{h}$, the ratio of the maximum amplitudes of reaction and dynamic forces is significant $\left(Q_{r}-Q_{d}\right) /_{Q_{d}}$, for a defect depth of $10 \mathrm{~mm}$.

The limit value of this damage depth for stable wheel travel is $H_{S H}=150 \mathrm{~mm}$. After exceeding this length, it is possible to derail the wagon, Fig. 7b. Attention should be paid to the rapid increase in the vertical reaction force $Q_{r}$, which in relation to the dynamic force $Q_{d}$ exceeds the value of 10. In practice, this will cause the rail to crack or break [15]. Less burdensome phenomena occur for the Squat defect pattern, shifted relative to the longitudinal axis of the rail by $P_{S Q}=12 \mathrm{~mm}$, Fig. 1e and Fig. 7c and 7d.The ratio of the mentioned forces does not differ much from unit at a low speed $\mathrm{V}=20 \mathrm{~km} / \mathrm{h}$, which clearly means a small impact of this defect on the vertical reaction forces $Q_{r}$. This is also confirmed by the analysis of the rail - wheel contact point in the case of a straight track, Fig. 8b compared to the defect pattern Split horizontal, Fig. 8a, for which disproportionately greater reaction forces were obtained. 
a)

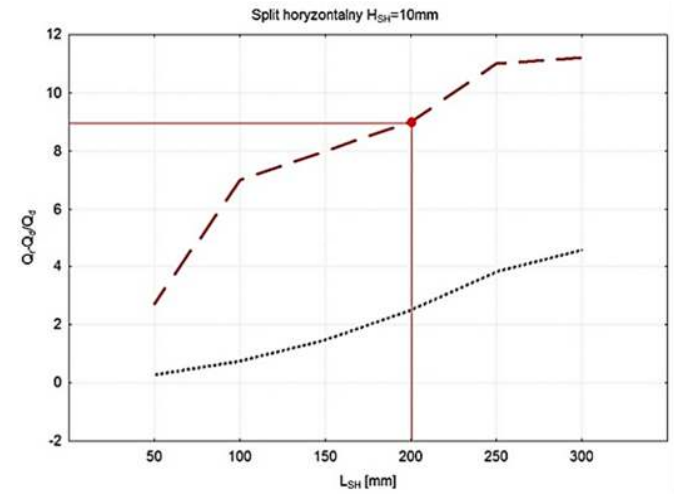

c)

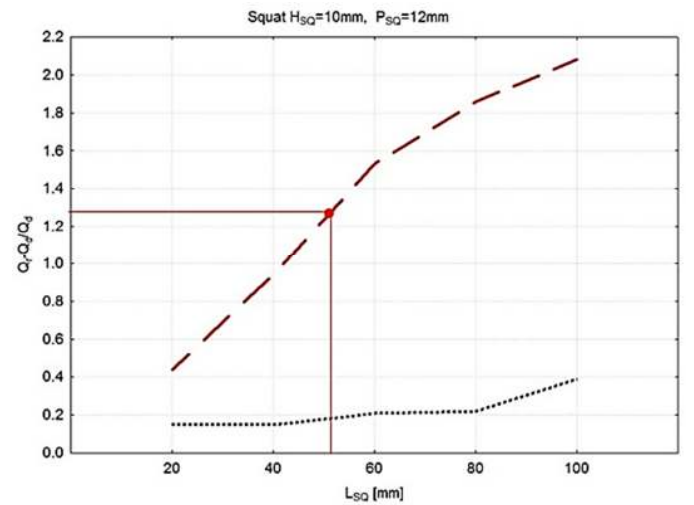

b)

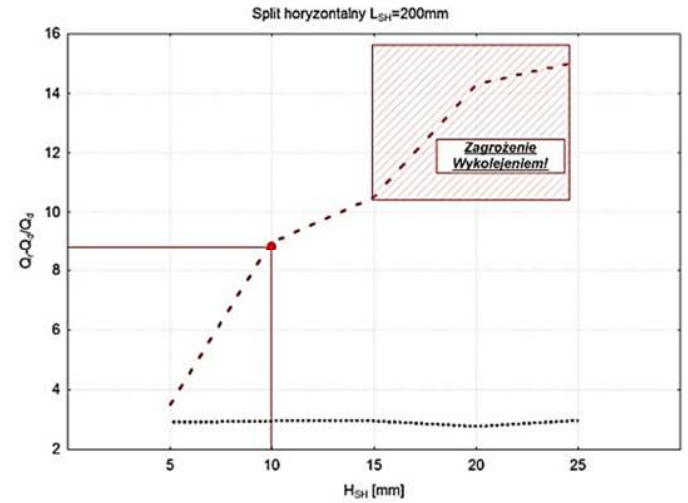

d)

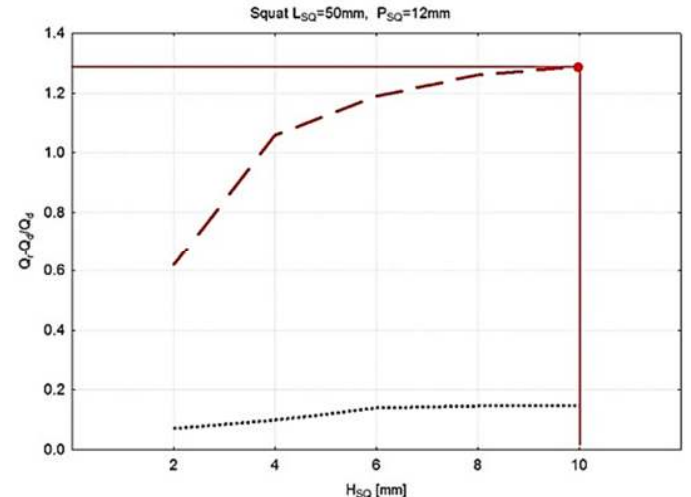

7. Illustration of the relationship between the relative amplitude of the contact force and the size of the defect patterns in rails, at different speeds: a) and b) Horizontal split as in fig. 1a, c) and d) Squat shifted as in Fig. 1e, where it is marked with a dashed line for V $=20 \mathrm{~km} / \mathrm{h}$ and a dotted line for $\mathrm{V}=80 \mathrm{~km} / \mathrm{h}$ (own study)

In addition, Fig. 8, for several defect patterns, shows all possible rail contacts with the wheel profile for various values of lateral displacement. Visible lines contained between the rail and wheel profiles indicate these contact points. The thick line corresponds to the current position of the mutual position of the wheel profile relative to the rail.

a)

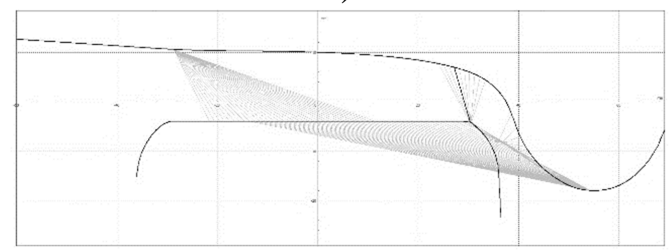

c)

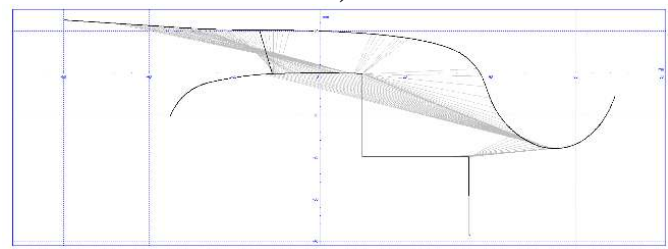

b)

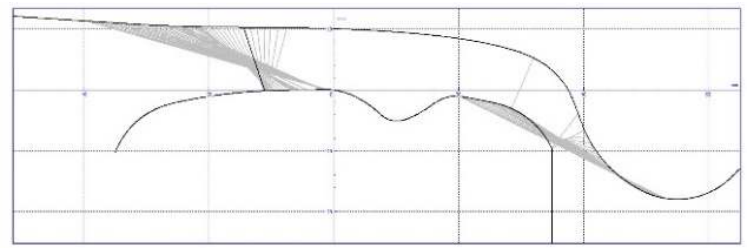

d)

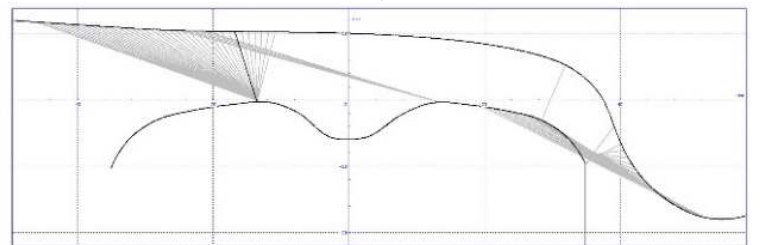

8. Illustration of rail contact areas - straight rim for defect patterns: a) Horizontal split, b) Squat shifted, c) Side split, d) Squat symmetrical about the rail axis (own study)

Defects belonging to this group, especially in large numbers occur on railway line curves, where the track profile and cant predispose these places to their formation. 


\section{Conclusions}

The simulation tests carried out at work and their analysis is the original achievements of the authors. They allow the determination of critical sizes of selected surface defects that may pose a threat to vehicle traffic, in practice their derailment. Simulation tests were carried out under specific simplifying assumptions, namely: a straight track, a dedicated freight wagon model with the adopted weight and loading, constant dynamic parameters of the subgrade (hard), standard defect shapes. The final action should be practical verification of the simulation tests obtained based on measurements of contact forces on real rail vehicles in various rail infrastructure conditions. A test track seems to be a useful place to go. The authors see that it is possible to create some calibration tools in this way that will allow assessing the geometry of surface defects in rails.

\section{Source materials}

[1] Canjea S., Lovejoy L.G.: TCRP Report 155: Track Design Handbook for Light Rail Transit. Second Edition. Chapter 2: Light Rail Transit Vehicles. Transportation Research Board of the National Academies, Washington, DC, 2012, s. 2.1-2.58.

[2] Beneberu A.: Rail Crack Analysis with Inspection and Maintenance Plan at Transition Section Between Bridges and Embankments. Addis Ababa University, 2016.

[3] Grulkowski S., Kędra Z., Zariczny J.: Problemy diagnostyki szyn kolejowych w torach i rozjazdach. Inżynieria Morska i Geotechnika, nr 5/2014, s. 497 -504.

[4] Katalog wad w szynach. UIC 712R, 2002.

[5] Kiciak P.: Podstawy modelowania krzywych i powierzchni. Zastosowania w grafice komputerowej. Wyd. WNT 2019.

[6] Lesiak P., Wlazło M.: Model optyczny skaterometrii laserowej wzorców wad powierzchniowych szyn kolejowych. Autobusy, Technika, Eksploatacja, Systemy Transportowe, $\mathrm{nr}$ 3/2013, s.1655 - 1664.

[7] Lesiak P., Podsiadło R.: Badania symulacyjne interakcyjnego oddziaływania uszkodzonych powierzchni kół zestawów kołowych w wózku wagonowym na tor kolejowy. Technika Transportu Szynowego, 12/2015, s. 913-919.

[8] Lesiak P., Podsiadło R., Stokłosa J.: Symulacyjne badania dynamicznego oddziaływania pojazdu na szyny $\mathrm{z}$ wadami powierzchniowymi. „Projektowanie, budowa i utrzymanie infrastruktury w transporcie szynowym" INFRASZYN 2018, Wyd. ITE-PIB Radom 2018, rozdział w książce, s. 135 -143.

[9] Migdal M.: Zarządzanie szynami z wadami squat. III SDIS Warszawa 2018.

[10] Pawełczyk M., Lesiak P., Podsiadło R.: Simulation study of the 4-axle wagon damaging impact on the track caused by some deformations of the wheel. $22^{\text {th }}$ International Conference, Current Problems in Rail Vehicles - PRORAIL 2015. Proceedings Vol. II, September 16 - 18, 2015, Žilina, Slovakia, s. 115-125.

[11] Podsiadło R.: Wspomaganie komputerowe w symulacji dynamiki ruchu pojazdów szynowych. Logistyka 6/2014, s. 8846-8850.

[12] Rail Defect Manual. Compiled by Sperry Rail Service for the use of the rail roads. Rev.5/16, 2016.

[13] Railway Investigation Report R15H0021. Main-track train derailment. Canadian National Railway Company, Ontario 2015.

[14] TMC 226, Rail Defects Handbook, RailCorp Engineering Manual - Track, Version 1.2, Issued June 2012.

[15] Towpik K.: Infrastruktura drogi kolejowej. Obciążenia i trwałość nawierzchni. Wyd. ITE - PIB, Warszawa - Radom 2006. 
[16] Track Inspector Rail Defect Reference Manual. Office of Railroad Safety, U.S. Departament of Transportation, Federal Railroad Administration, July 2015, Revision 2.

[17] Universal Mechanizm - ver.6.0, Help Documentation, Laboratory of Computational Mechanics Brayansk State Technical University. Getting Started: Railway Vehicle Dynamics. 